\title{
Proibicionismo e a criminalização de adolescentes pobres por tráfico de drogas*
}

\section{Prohibitionism and the criminalization of poor adolescents for drug traffic}

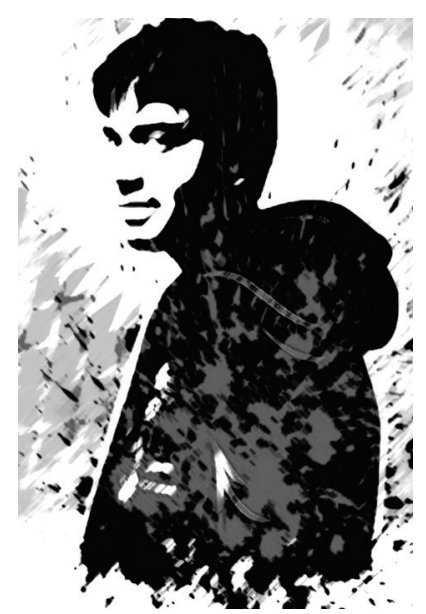

Andréa Pires Rocha**

Resumo: O proibicionismo, a "guerra às drogas" e a criminalização da pobreza são elementos situados no âmbito político e ideológico, se materializam na luta de classes e são utilizados para o controle social. Mostramos a partir de alguns trechos de sentenças judiciais e manifestação do Ministério Público, o quanto os discursos ideologizados justificam a criminalização de adolescentes pobres por tráfico de drogas, colocando-os como inimigos sociais sem considerar as contradições e riscos que são submetidos cotidianamente.

Palavras-chave: Proibicionismo. Adolescentes. Tráfico de drogas. Criminalização da pobreza. ECA. Lei Antidrogas (Sisnad).

\begin{abstract}
The prohibitionism, the "war against drugs" and the criminalization of poverty are elements in the political and ideological context, they have materialized themselves in the class struggle and they are used for social control. From excerpts taken from court decisions and manifestations of the Department of Justice, we show how much the ideologized discourses justify the criminalization of poor adolescents for drug traffic and place them as social enemies. Such discourses do not consider the contradictions and risks to which such adolescents are submitted daily.
\end{abstract}

Keywords: Prohibitionism. Adolescents. Drug traffic. Criminalization of poverty. ECA. Antidrug Law (SISNAD).

* Este artigo é parte das reflexões desenvolvidas na tese de doutorado Trajetórias de adolescentes apreendidos como "mulas" do transporte de drogas na região da fronteira (Paraná) Brasil - Paraguai: exploração de força de trabalho e criminalização da pobreza, na qual tivemos como objeto, a "análise das trajetórias e contradições que determinam o cotidiano de adolescentes que são explorados como 'mulas' na rota internacional do tráfico de drogas existente no Estado do Paraná, região de fronteira entre Brasil-Paraguai”.

** Doutora em Serviço Social pela Unesp-Franca, São Paulo, Brasil; mestre em Educação pela Universidade Estadual de Maringá (UEM)/Paraná, Brasil. Graduada em Serviço Social pela Unesp-Franca. E-mail:drea_rocha@yahoo.com.br. 


\section{Drogas, proibicionismo e controle dos pobres}

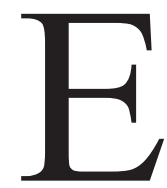

ntendemos que os discursos ideologizados com base no proibicionismo fazem com que os adolescentes trabalhadores do tráfico de drogas ${ }^{1}$ ganhem status de traficantes perigosos e recebam o estigma de inimigos sociais, justificando a criminalização da juventude pobre e a efetivação do estado penal. Por isso, inverteremos o trivial e iniciaremos esta seção com a apresentação de dois fatos concretos, portanto anteciparemos fragmentos de nossa pesquisa de campo trazendo alguns exemplos de como a combinação "proibicionismo-criminalização da pobreza" ainda subsidia decisões do Ministério Público, do Poder Judiciário e de equipes técnicas, incluindo profissionais de Serviço Social. Talvez o verossímil dos argumentos abaixo justifique o debate que utilizaremos no decorrer do artigo.

Apresentaremos um trecho da manifestação do Tribunal de Justiça, que "justifica" a determinação da privação de liberdade de adolescente explorado pelo narcotráfico que foi apreendido em ônibus interestadual com quatro tabletes de maconha, totalizando $4.430 \mathrm{~kg}$. Vejamos,

A sensação generalizada da população, especialmente a de menor grau de cultura, ou seja, a absoluta maioria, é que o Brasil é uma terra sem lei e sem justiça, onde a corrupção, a bandalheira e a impunidade reinam soberanas. Para outros segmentos da população, um pouco mais esclarecidos, é a de que, no Brasil, a legislação é de uma frouxidão irritante, em que a lei só existe para favorecer quem comete irregularidade, barbaridade ou crimes. Diz-se, à boca pequena, que matar, roubar, estuprar ou traficar podem causar penas relativamente graves, mas que, com toda certeza, não serão cumpridas, pois é uma tal de progressão de regime, de remissão de pena, de livramento condicional, que, para alguém ser segregado, mesmo depois de condenado, só se for pobre ou marginalizado. A sensação da população é a de que o Brasil não tem mais jeito! As brechas na lei são muitas e sempre bem exploradas, bastando, para tanto, ter bons advogados, o que, evidentemente, uma boa conta bancária sempre consegue. Isto é triste. Chegou-se a uma tal situação que o homem honesto, como já afirmava o sempre lembrado Rui Barbosa, chega a ter vergonha de ser bom. Mas isso há de mudar! Esta é a esperança. Esperança é a profissão do brasileiro.

1. Nos pautamos no Decreto n. 3.597, de 12 de setembro de 2000 (Brasil, 2000), que promulga a Convenção 182 e a Recomendação 190 da Organização Internacional do Trabalho (OIT) a qual considera o tráfico de entorpecentes uma das piores formas de trabalho infantil. 
Em [nome da cidade], a sensação não é diferente, e as pessoas, nas ruas, nas escolas, nos bares, nas igrejas, em casa, na imprensa, parodiando Cícero, nas Catilinárias e se dirigindo aos poderes da República, estão a perguntar: até quando, autoridades, abusareis de nossa paciência? Este clamor da comunidade é traduzido por um silogismo elementar: quem erra deve ser punido e quem erra gravemente deve ser punido severamente, o crime é um erro grave, logo, os criminosos devem ser severamente punidos. [...]. (Sentença 1)

No trecho acima o juiz desenvolve um discurso penalista muito claro, dando, a nosso ver, demasiado peso ao ato infracional, o discurso ideologizado mostra nas entrelinhas um moralismo exacerbado e extrema ausência de historicidade para a compreensão das raízes da criminalidade como um fenômeno que deve ser entendido a partir da contextualização sócio-histórica. É contraditório, pois ao mesmo tempo em que o magistrado profere a existência da impunidade para aqueles que possuem "dinheiro", julga de maneira voraz e culpabilizatória um adolescente pobre. Vejamos a continuidade da sentença,

[...] Nestes conceitos populares de crime e de punição, também se incluem os adolescentes. Na atual quadra da civilização, em pleno século XXI, quando os meios de comunicação e a internet penetram em todas as casas, quando o próprio Supremo Tribunal Federal tem entendido, por exemplo, que a presunção de violência para menores de 14 anos, nos crimes sexuais, já não é absoluta, porque uma pessoa de 13 ou 12 anos já não pode se dizer desconhecedora das coisas de sexo, a população se indaga: é inexperiente e absolutamente desinformada uma pessoa de 15, 16 ou 17 anos que trafica, que mata, que rouba, que seqüestra, que estupra? Se for vítima, ela não é inexperiente ou desinformada, mas é se for autor? [...] (Sentença 1)

O documento apresenta uma sequência de afirmações preconceituosas, criminalizatórias e contra a garantia dos direitos humanos de crianças e adolescentes. Reproduz o discurso do senso comum, que, via de regra é utilizado para a defesa da "redução da maioridade penal", criminalizando adolescentes e fortalecendo a ideia errônea de que a maioria dos adolescentes infratores comete ato infracional grave. Ao final aborda a questão do tráfico de drogas colocando que,

[...] O tráfico de entorpecentes, seja como crime, seja como ato infracional, é conduta gravíssima. O que poderá lhe fazer quem entregou a droga ou quem dele iria recebê-la? Assim, havendo indícios suficientes da autoria e materialidade, mantém-se a 
internação provisória do paciente, uma vez demonstrada a sua necessidade imperiosa ante a extrema gravidade do ato infracional (tráfico de entorpecentes) e, ainda, como garantia da ordem pública (parágrafo único do art. 108 c/c art. 174 do ECA), no intuito de proteger o adolescente, é necessário que ele fique custodiado, a fim de que possa ser acompanhado por profissionais que o orientem.

Isto posto, diante do clamor público, que traduz o anseio da sociedade em garantir a ordem pública e no intuito de proteger o adolescente, visto que não se sabe o que poderá ocorrer com ele, da parte de quem lhe entregou a droga, caso ele seja liberado agora, decreto a custódia provisória de [...] na inicial, pelo prazo de 45 dias! (Sentença 1).

Contrapondo "bem e mal", o juiz reproduz o discurso da "guerra às drogas", colocando que "[...] o tráfico de entorpecentes, seja como crime, seja como ato infracional, é conduta gravíssima." Porém, ao final do documento, coloca que irá manter o adolescente privado de liberdade para protegê-lo de seus contratantes, materializando outra vertente do discurso penalizatório que vincula encarceramento com "proteção". Como explica Loïc Wacquant (2010), no neoliberalismo as políticas sociais são desmontadas e as políticas penais fortalecidas, submetendo o proletariado a uma dupla regulação que envolve o setor assistencial e penal. Além disso, enfatiza que a polícia, os tribunais e as prisões (o que chamamos de Sistemas de Segurança e Justiça) são instituições de controle voltadas principalmente para as categorias de sujeitos em situação de vulnerabilidade social. Vejamos outro exemplo,

[...] É importante salientar que a adolescência é o período de desenvolvimento do ser humano, assim, é primordial a imposição de regras de conduta para convivência na sociedade. É preciso estabelecer limites para a formação da pessoa com princípios e consciência que os atos praticados de forma errônea acarretarão consequências em seu desfavor. Ressalta-se que o objetivo da aplicação de medida socioeducativa é garantir o caráter pedagógico e ressocializante, haja vista o adolescente ser sujeito de direitos e pessoa em situação peculiar de desenvolvimento, sendo primordial a imposição de regras de conduta para que o adolescente viva harmoniosamente em sociedade, e que tenha referência, apoio e segurança. Isto posto, JULGO PROCEDENTE a representação em face do representado [...] pela prática de ato infracional tipificado como crime no artigo 33, caput da Lei n. 11.343/06, e aplico ao mesmo a medida socioeducativa prevista no artigo 112, inciso VI (internação), do ECA, devendo ser reavaliada no máximo a cada seis meses, conforme artigo $12 \S 2^{\circ}$., do mesmo diploma legal. Considerando que o representado foi apreendido em flagrante e foi determinada a sua internação provisória, bem como se expõe em situações de risco face suas con- 
dutas sem regras e sem limites socialmente aceitos, aliado ao fato de possuir antecedentes infracionais, nego-lhe o direito de apelar em liberdade, motivo pelo qual determino a sua imediata internação [...]. (Sentença 2).

É fácil constatarmos nos trechos acima a dupla regulação, porém, este tipo de encaminhamento não é exceção, pois a pesquisa mostrou que via de regra os juízes penalizam os adolescentes trabalhadores do tráfico com medidas socioeducativas privativas ou restritivas de liberdade, pautando-se no ECA - Estatuto da Criança e do Adolescente, afirmando que irão "protegê-los", punindo-os, o que chamamos na tese de "contra-proteção".

Vejamos agora um terceiro exemplo, que é a manifestação do Ministério Público em situação de adolescente do sexo feminino de 16 anos, moradora de região próxima da capital paulista, apreendida com um adulto em uma viagem de automóvel da região da fronteira para o estado de São Paulo, onde transportavam trinta e quatro quilos de maconha,

De acordo com os elementos carreados no caderno investigatório, no dia [...], a adolescente foi flagrada, quando, na companhia de maior imputável, transportava larga quantidade de "maconha" para o Estado de São Paulo.

Na delegacia de polícia manteve-se calada [...] No Ministério Público, relatou que mantinha relacionamento extraconjugal com o coautor, o qual havia feito convite, que ela acreditava tratar-se de viagem de cunho romântico para Foz do Iguaçu. Ao retornar, usaram veículo, que ele disse ter sido arrematada em Leilão da Receita, no qual, sem ela saber, a droga era transportada. [O homem] buscou o carro no Paraguai e não deixou a representada acompanhá-lo e, no caminho, depois de ligar o ar, ela sentiu o cheiro característico da maconha, mas optou pelo silêncio, assentindo com a conduta. Há depoimento dos policiais militares que surpreenderam a representada e o maior e, diante do nervosismo, resolveu vasculhar o veículo, encontrando a droga. [...] A materialidade deflui do auto de prisão em flagrante delito e apreensão por ato infracional de [...], em especial do auto de constatação provisória de substâncias entorpecentes [...] e os indícios de autoria residem no flagrante ocorrido e nos depoimentos colhidos nos autos, como já analisado, justificando, assim, o recebimento da representação. [...] (Manifestação do Ministério Público 1)

A situação acima difere-se da relatada anteriormente, pois a quantidade de maconha é considerada razoável. Todavia, o documento demonstra a ausência de preocupação com a adolescente, pois o promotor apenas a culpabiliza colocando-a no mesmo patamar do adulto, não considerando a hipótese da mesma ter sido 
realmente enganada e coagida. Além disso, reforça o discurso proibicionista, justificando a denúncia e sugerindo medida de internação,

[...] Outrossim, é de se alarmar que pessoa tão jovem como a representada esteja tão profundamente envolvida com a mercancia ilegal, sendo imperativa a intervenção repressiva do Estado, por meio de internação. Ademais, o reclamo da ordem pública, em situações como a presente, justifica a tomada desta medida, agindo de forma a coibir a repudiosa prática de traficância. Por derradeiro, ela já é mãe, vivia em união estável e não hesitou em deixar os filhos e empreender viagem com pessoa que mal conhecia, para cidade fronteiriça. (Manifestação do Ministéiro Público 1).

Vemos que a situação da adolescente é de alto risco, pois aparentemente foi usada pelo adulto como álibi para viagem. Estava a mil quilômetros de sua residência, já é mãe, dentre outras questões, mas a preocupação foi somente com relação à "repudiosa prática de traficância". Que repúdio é este? De onde vem este repúdio à traficância? Será que essa repugnância sempre existiu? O uso de todas as drogas/ substâncias psicoativas é repudioso? Ou somente o uso de substâncias que são normativamente proibidas?

É a partir da expressão "repúdio" que continuaremos o debate proposto, pois pretendemos mostrar o quanto os valores e ideologias que constroem o pensamento proibicionista levam à criminalização e ao controle de pessoas, em especial jovens pobres. Para isso é essencial que mostremos pelo menos uma definição do que é droga. Optamos, portanto, pela explicação de Escohotado (2004, p. 9): "uma substância que, em vez de 'ser vencida' pelo corpo (e assimilada como simples nutriente), é capaz de 'vencê-lo', provocando - em doses insignificantemente pequenas quando comparadas com as de outros alimentos — grandes alterações orgânicas, anímicas ou de ambos os tipos". Enfatiza que:

A particular história das drogas ilumina a história geral da humanidade com uma luz própria, como quando abrimos a janela até então fechada pelo horizonte, e aparecem as mesmas coisas sob uma perspectiva nova. (Escohotado, 2004, p. 7)

Sabemos, portanto, que historicamente as substâncias psicoativas satisfazem necessidades que podem ser físicas, culturais, religiosas, ritualísticas etc. ou seja, essas substâncias acompanham a história do homem. Neste contexto, o autor Henrique Carneiro (2002, p. 116-117) enfatiza que 
A primeira questão a se definir é a de que as drogas são necessidades humanas. Seu uso milenar em quase todas as culturas humanas corresponde a necessidades médicas, religiosas e gregárias. Não apenas o álcool, mas quase todas as drogas são parte indispensável dos ritos de sociabilidade, cura, devoção, consolo e prazer. Por isso, as drogas foram divinizadas em inúmeras sociedades.

A droga como produto desenvolve um papel social e cultural na história da humanidade, extrapolando épocas e tempos. Entretanto, historicamente, a droga, que poderia ser reconhecida apenas como um produto advindo de métodos naturais e/ou artesanais, com valor de uso particularizado, ganha novas significações na sociedade burguesa, transformando-se em droga-mercadoria, passando a ter, portanto, valor de troca. Koutouzis (1997) coordenou a construção do Atlas Mondial des Drogues, desenvolvido pelo Observatoire Géopolitique des Drogues, e logo na introdução aponta que a partir do século XIX o uso e a produção de drogas sofreram grandes transformações, que fazem parte do processo da Revolução Industrial, sendo transformadas quimicamente para consumo indistinto e maciço em formas quase idênticas (pó, líquido, comprimidos). Além disso, às vezes têm sido substituídas por drogas sintéticas.

Nesse contexto, as drogas (proibidas ou não) são mercantilizadas, produzidas e distribuídas a partir das relações estabelecidas no modo de produção capitalista. A produção em larga escala, modificada técnica e cientificamente, explora mais-valia do trabalho humano ${ }^{2}$, tornando-se um lucrativo negócio. Estabelece-se, dessa maneira, uma forma particular de trabalho, o qual se materializa na produção, distribuição e venda da droga-mercadoria. Ressaltamos, portanto, que há uma imensa diferença no entendimento histórico da droga-produto, que possuía apenas valor de uso, em relação a droga-mercadoria, que possui, antes de tudo, valor de troca. É essencial considerarmos que a droga-mercadoria só ganha status de mercadoria na sociabilidade burguesa por ser um objeto suscetível à mercantilização, que de uma maneira ou outra satisfaz necessidades de alguns sujeitos, ou seja, aqueles capazes de pagar um preço por ela.

Entender as drogas como mercadorias é entender que são produzidas justamente para a satisfação de necessidades de necessidades humanas, pois, como nos explica Marx (1988, p. 42),

2. Refletiremos sobre o significado do trabalho nas relações de produção, circulação e venda de substâncias psicoativas proibidas na segunda seção deste capítulo. 
A mercadoria é, antes de mais nada, um objeto externo, uma coisa que, por suas propriedades, satisfaz necessidades humanas, seja qual for a natureza, a origem delas, provenham do estômago ou da fantasia. Não importa a maneira como a coisa satisfaz a necessidade humana, se diretamente, como meio de subsistência, objeto de consumo, ou indiretamente, como meio de produção.

Destaquemos a afirmação de Marx: "satisfaz necessidades humanas, seja qual for a natureza, a origem delas, provenham do estômago ou da fantasia", pois neste caso, o padrão moral ou de legalidade não é determinante. E se a necessidade do uso de drogas não pode ser satisfeita por meios legais, os homens buscarão novas maneiras de satisfazê-la. Portanto, todo o discurso ideologizado que demoniza as drogas, bem como os fundamentos religiosos e as ações proibicionistas não fazem com que as substâncias psicoativas deixem de existir. Por isso a proibição de algumas drogas não garante diminuição ou fim do uso; ao contrário, a proibição torna o negócio mais lucrativo, como aponta Thiago Rodrigues (2003, p. 12),

[...] os produtos comercializados [...] são substâncias amplamente desejadas e que são hoje ilegais. Tal ilegalidade significa que o circuito de produção e venda de inúmeros compostos químicos é proibido de existir segundo leis específicas [...] essas leis, no entanto, não bastam para erradicar a procura por tais substâncias, fato que impulsiona um rentável negócio clandestino que se dedica a fazer chegar ao consumidor sua droga preferida.

Enfim, a qualificação das drogas que podem ou não ser usadas e a construção de políticas repressivas geram efeitos contrários aos que o discurso proibicionista defende, e por mais que se proíba, o uso não cessa. Fernandez (1997, p. 120) aponta que o proibicionismo cria novas questões associadas ao uso de substâncias psicoativas e, especialmente, agrega valor à mercadoria. Segundo ele, "as drogas são mercadorias, cuja proibição vem possibilitando lucros extraordinários e consolidando uma poderosa economia ilegal [...]. O proibicionismo e a política de guerra se mostraram um fracasso como política de controle de drogas". Já Carneiro (2002, p. 127) ao tratar a questão do lucro, traz o debate para a questão do "controle estatal" pois, segundo ele,

A noção de um Estado investido do poder de polícia mental e comportamental, que legisla sobre os meios botânicos e químicos de que os cidadãos se utilizam para interferir em seus estados de humor e de consciência e que pune os que desobedecem é 
um pressuposto necessário para a hipertrofia do lucro obtido no tráfico. Em outras palavras, a proibição gera o superlucro. Por essas razões, a reivindicação da descriminação das drogas choca-se tanto com os interesses dos grandes traficantes assim como com os do Estado policial.

São muitos os autores que compartilham da tese de Carneiro (2002), haja vista que a manutenção da proibição sofre múltiplas determinações. A questão da ilegalidade do uso de algumas substâncias psicoativas decorre de normativas determinadas por diversos elementos, os quais, dependendo da conjuntura econômica, social e histórica, pendem para o "lado" da proibição ou da permissão. Como destaca Passetti (1991, p. 37), “a legalidade/ilegalidade das drogas é uma resultante histórica do Estado moderno: conjunto de verdades sustentando o poder calcado em relações econômicas e políticas". Em síntese, podemos refletir que a determinação do que pode ser "livre" ou não é conjuntural e sofre múltiplas determinações.

Segundo Rodrigues (2003, p. 25), muitos se surpreendem ao saber que no século passado era possível a compra de cocaína e seus derivados em farmácias, até mesmo nos Estados Unidos, país que no século XX assumiu a vanguarda da cruzada antidrogas. Explica que depois da Guerra Civil norte-americana (1861-65), alguns grupos, envolvidos com igrejas e instituições protestantes, passaram a exigir ações severas do governo para conter a produção, venda e consumo de substâncias psicoativas. Nesse contexto, constroem-se movimentos proibicionistas, pautados na tradição puritana do protestantismo calvinista, os quais conquistaram espaços e garantiram legislações naquele país e, paulatinamente, foram impondo o proibicionismo para o restante do mundo. De acordo com Delmanto (2010, p. 35), o grande foco do combate foi o álcool e as substâncias consumidas por diversos setores da população dos EUA, eram associados de maneira criminalizatória contra as

minorias e grupos imigrantes: o ópio aos chineses, a maconha aos mexicanos e a cocaína aos negros. Desde seu princípio, a estratégia de modelo penal no trato de substâncias psicoativas teve como alvo setores da população que o Estado desejava controlar. (Delmanto, 2010, p. 35)

Vemos o quanto a "guerra às drogas" é utilizada como instrumento legitimador para a perseguição aos pobres. É uma guerra contra as pessoas, exacerbando a violência do poder punitivo. Como explica Karam (2012), o paradigma da "guerra" é utilizado para construir o "inimigo" que deve ser eliminado: 
A "guerra às drogas", como quaisquer outras guerras, é nociva, insana e sanguinária. A "guerra às drogas" não se dirige propriamente contra as drogas. Dirige-se, sim, como quaisquer outras guerras, contra pessoas - os produtores, comerciantes e consumidores das substâncias proibidas, especialmente os mais vulneráveis dentre eles, os mais pobres, marginalizados, desprovidos de poder, que são as maiores vítimas da violência causada pela irracional insistência na proibição das selecionadas substâncias psicoativas tornadas ilícitas.

Neste sentido, é essencial observarmos o quanto a ideologia proibicionista influencia a consciência que se tem a respeito das "drogas ilícitas" e da política de combate, fazendo com que coloquemos a questão das "drogas" no âmbito da Segurança Pública, não permitindo que pensemos a questão a partir do âmbito da liberdade, nos afastando da percepção de que o controle social está por trás disso, pois na maioria das vezes, quando se trata de ações voltadas a jovens e adolescentes envolvidos direta ou indiretamente com drogas, aos jovens pobres é atribuído o status de traficantes perigosos, que devem ser detidos e aos de classe média e alta, o status de usuários que devem ser protegidos. ${ }^{3}$

\section{2. "Lei Antidrogas" brasileira (SISNAD) utilizada como instrumento para penalização de adolescentes pobres}

A regulamentação e a proibição do uso de algumas substâncias psicoativas no Brasil é bem recente, ganhando força no século XX, a partir da influência de políticas proibicionistas dos EUA, as quais foram impostas como modelos a serem seguidos por todo o mundo. Rita de Cássia Lima (2009), explica que na década de 1910 a imprensa brasileira passa a difundir medidas repressivas ao "risco" do uso lúdico e descontrolado das drogas. Segundo ela, as áreas da medicina (psiquiatria) e do direito penal, a partir de vertentes criminalizadoras às drogas, tornam-se os principais agentes para construção de legislações e políticas públicas proibicionistas. Até então, segundo Tiago Rodrigues (2003), as drogas eram utilizadas apenas pelas elites brasileiras, porém,

3. E quando os usuários são pobres, devem ser retirados de circulação à força, como temos visto nas políticas construídas para o "combate ao crack". 
[...] a perseguição aos venenos chics cresce quando essas drogas deixaram de ser tão exclusivas. O pequeno aumento do uso de cocaína e heroína registrado entre prostitutas, cafetões e pequenos marginais, acrescido do preconceito há muito consolidado contra o uso de maconha (vista como droga de negros), auxiliou na produção de um ambiente favorável ao controle desses psicoativos. [...]. (Rodrigues, 2003, p. 77)

A primeira lei antidrogas do país promulgada em 1921 criminaliza o vendedor ilegal e vitimiza o usuário, materializando no Brasil os princípios da Lei Harrisson Narcotic Act, de 1914 dos EUA. ${ }^{4}$ Nessa perspectiva, o usuário é considerado doente, necessitando de reabilitação para a vida social. Por outro lado há o agravamento da criminalização dos vendedores ilegais, os quais são considerados,

em sua maioria, a "ralé" social e moral de então: cafetões, prostitutas, cafetinas, estrangeiros e profissionais da saúde "corrompidos pela cobiça". Em uma palavra, estão isolados numa categoria controlável e identificável — segmentos cuja atividade lucrativa e influente era subversiva à ordem social vigente. Provindos de classes baixas e praticando atividades consideradas imorais por tal ordem, estes estratos são, pela lei de 1921, enquadrados num campo de ilegalidade que os vulnerabiliza ante um Estado que agora está dotado de recursos legais para reprimir não só o tráfico de drogas como também essas outras "ocupações degeneradas" a ele estritamente vinculadas. (Rodrigues, 2003, p. 136)

O pesquisador aponta que o decreto-lei de 1921 reproduz juízos morais e sociais contra as drogas, os quais se deslocaram do nível religioso para o técnico-ético, sanitário e de segurança pública estatais. Vemos, portanto, que historicamente sempre houve a distinção entre usuário e traficante, materializando, desta forma, distinção de classe social, pois, via de regra, atribui-se aos jovens pertencentes às classes socioeconômicas mais favorecidas o status de usuário e aos jovens de classes socioeconômicas vulneráveis, o status de traficantes.

Com o passar do tempo, as legislações de controle do uso de drogas no país sofreram algumas modificações, porém a essência do princípio vitimização do usuário X criminalização do traficante continuou presente em todas elas. Em 2002

4. Tiago Rodrigues (2003, p. 30) explica que "o texto citava as figuras do traficante e do viciado, respectivamente aquele que produz e comercializa drogas psicoativas irregularmente e aquele que consome sem permissão médica. O traficante deveria ser perseguido e encarcerado; o usuário, considerado doente, deveria ser tratado (mesmo que compulsoriamente)". 
há a promulgação da Lei n. 10.409 (Brasil, 2002) que, segundo Rodrigues (2003, p. 78) "institui definitivamente as figuras do traficante, criminoso que deve ser punido com rigidez e do usuário, indivíduo incapaz que deve ser encaminhado para tratamento". Vera Malaguti Batista (2003) já estava problematizando a questão da lei de 2002, apontando que a questão de descriminalizar o usuário e aumentar a criminalização do traficante é perversa, pois a "descriminalização" é voltada para o usuário da classe média, que já é "descriminalizado". Nas palavras dela:

Por onde a questão das drogas sangra literalmente é no tráfico. Então, você tem isso de descriminalizar o usuário mas manter a criminalização do traficante. Que virou uma categoria fantasmática, o traficante é o demônio, ele não tem casa, não tem mãe; [...]. A descriminalização do usuário poderia ser o começo de uma legislação geral, mas como eles estão legislando para o Posto Nove, ${ }^{5}$ fica uma coisa perversa, porque quem já está descriminalizado será descriminalizado e onde está sangrando, que é na periferia, aumenta-se a hemorragia. (Batista, 2003, p. 30)

A síntese da socióloga levanta inúmeras questões a respeito da lei de 2002 e dos problemas que viriam a seguir e persistem até hoje, pois em 23 de agosto de 2006 foi revogada a Lei n. 10.409, de 11/1/2002, e foi instituída a Lei n. 11.343, que constitui o Sisnad - Sistema Nacional de Políticas Públicas sobre Drogas (Brasil, 2006) que "prescreve medidas para prevenção do uso indevido, atenção e reinserção social de usuários e dependentes de drogas; estabelece normas para repressão à produção não autorizada e ao tráfico ilícito de drogas; define crimes e dá outras providências", conhecida como a "nova lei antidrogas". Esta lei tem grande repercussão, pois abranda as sanções para os usuários de drogas (tratamento, prestação de serviço comunitário) e torna mais rígidas as penas direcionadas aos traficantes (reclusão de cinco a quinze anos), mantendo, portanto, a lógica das legislações anteriores. Entretanto, a lei deixa para os juízes identificarem, com base na denúncia e nas provas contidas nos processos se a quantidade apreendida pode ser considerada para o consumo ou tráfico. Vejamos:

Art. 28. Quem adquirir, guardar, tiver em depósito, transportar ou trouxer consigo, para consumo pessoal, drogas sem autorização ou em desacordo com determinação legal ou regulamentar será submetido às seguintes penas:

I - advertência sobre os efeitos das drogas;

5. Posto na praia de Ipanema, onde se concentram os usuários de drogas proibidas, pertencentes à classe média e alta. 
II — prestação de serviços à comunidade;

III - medida educativa de comparecimento a programa ou curso educativo.

$\S 1^{\circ}$ Às mesmas medidas submete-se quem, para seu consumo pessoal, semeia, cultiva ou colhe plantas destinadas à preparação de pequena quantidade de substância ou produto capaz de causar dependência física ou psíquica.

$\S 2^{\circ}$ Para determinar se a droga destinava-se a consumo pessoal, o juiz atenderá à natureza e à quantidade da substância apreendida, ao local e às condições em que se desenvolveu a ação, às circunstâncias sociais e pessoais, bem como à conduta e aos antecedentes do agente.

$\S 3^{\circ}$ As penas previstas nos incisos II e III do caput deste artigo serão aplicadas pelo prazo máximo de 5 (cinco) meses.

O artigo acima é eminentemente destinado aos usuários de substâncias psicoativas. Não há a determinação de uma quantidade de drogas, havendo inclusive a menção de que o juiz considerará a natureza e a quantidade a partir do "local e às condições em que se desenvolveu a ação, as circunstâncias sociais e pessoais". Desta forma, podemos constatar a subjetividade em que a materialidade do "crime" é determinada. Agora vejamos outro artigo da mesma lei:

Art. 33. Importar, exportar, remeter, preparar, produzir, fabricar, adquirir, vender, expor à venda, oferecer, ter em depósito, transportar, trazer consigo, guardar, prescrever, ministrar, entregar a consumo ou fornecer drogas, ainda que gratuitamente, sem autorização ou em desacordo com determinação legal ou regulamentar:

Pena - reclusão de 5 (cinco) a 15 (quinze) anos e pagamento de 500 (quinhentos) a 1.500 (mil e quinhentos) dias-multa.

$\S 1^{\circ}$ Nas mesmas penas incorre quem:

I - importa, exporta, remete, produz, fabrica, adquire, vende, expõe à venda, oferece, fornece, tem em depósito, transporta, traz consigo ou guarda, ainda que gratuitamente, sem autorização ou em desacordo com determinação legal ou regulamentar, matéria-prima, insumo ou produto químico destinado à preparação de drogas;

II - semeia, cultiva ou faz a colheita, sem autorização ou em desacordo com determinação legal ou regulamentar, de plantas que se constituam em matéria-prima para a preparação de drogas;

III - utiliza local ou bem de qualquer natureza de que tem a propriedade, posse, administração, guarda ou vigilância, ou consente que outrem dele se utilize, ainda que gratuitamente, sem autorização ou em desacordo com determinação legal ou regulamentar, para o tráfico ilícito de drogas. 
Já esse artigo é destinado aos "traficantes", pois se inclui na descrição do crime os verbos, "fabricar", "vender", “oferecer", "transportar", os quais traduzem ações "dignas" de punição mais severa. Todavia, ao refletirmos sobre os dois artigos, não vemos uma diferença que perpassa a questão que temos discutido até então neste texto: a demonização do traficante e a vulnerabilização do usuário. Pois se a quantidade não é a única prova que determina a materialidade do crime de tráfico de drogas, supomos que o fator determinante da materialidade é a condição subjetiva da apreensão. Ou seja, a determinação fica a cargo da leitura dos primeiros que se deparam com a situação, que são, via de regra, policiais e delegados, os quais irão descrever o boletim de ocorrência conduzindo para um lado ou outro.

Será que quando ocorre uma apreensão de substância psicoativa ilegal em um barraco de periferia considera-se a hipótese de que aquela pessoa é usuária? Será que em uma apreensão ocorrida em uma casa de classe média/alta a pessoa poderá ser considerada traficante? Claro que de acordo com o compromisso ético dos componentes do Sistema de Segurança e Justiça, os elementos estereotipados não podem ser determinantes, mas infelizmente a Lei Antidrogas conta prioritariamente com o "olhar" dos agentes de segurança e com o "bom-senso" do juiz, e isso é demasiadamente subjetivo. Neste contexto, Maronna (2006) reflete que "a nova lei de drogas representa mais do mesmo: a opção pelo modelo proibicionista e sua política criminal bélica, com derramamento de sangue", alertando que "o alardeado abrandamento do tratamento dado ao porte para consumo pessoal é, na verdade, uma cortina de fumaça com o objetivo de contrabalançar o agravamento da punição ao tráfico" (Maronna, 2006, p. 2).

Quem são usuários? Quem são traficantes? É neste ponto que justificamos o porquê de todo este debate, pois a diferença no tratamento entre traficante e usuário abre brechas para a criminalização dos jovens pobres. Como temos discutido desde o início deste artigo, a "guerra às drogas" é um instrumento para o controle social, pois, como enfatiza Labrousse (2010, p. 13):

A guerra às drogas envolve Estados e grupos não estatais que circulam pelo planeta, mas que também se fixam em favelas, becos, morros, selvas. Nessa guerra, há soldados de colarinho-branco e computadores e, também, soldados de chinelos e metralhadoras.

É uma guerra difusa, desleal e desigual. De um lado, controle de opções individuais, pois as pessoas deveriam ter a liberdade de se entorpecer; do outro lado, 
o controle das classes chamadas "perigosas". Certamente, os fundamentos ideológicos que se constroem acerca do tráfico de drogas criminalizam a pobreza. As chamadas políticas de combate ao tráfico de drogas desenvolvem-se a partir da prisão de pessoas que estão, via de regra, vivendo em morros e bairros periféricos dos centros urbanos e deixando sem penalização pessoas e grupos que estão na ponta das redes e/ou realizam crimes e ações ilegais de outras espécies. De forma bem interessante, o autor D'Elia Filho (2008, p. 115), mostra que

No Brasil, a "guerra contra as drogas" é o carro-chefe da criminalização da pobreza, através dos discursos de lei e ordem disseminados pelo pânico. Bala perdida, roubo de veículos, queima de ônibus e até o comércio de produtos por camelôs são diferentes prática ilícitas imputadas aos "traficantes".

Essa realidade também se materializa na questão dos adolescentes trabalhadores do tráfico de drogas, tendo em vista que estes são tratados como traficantes, não havendo a consideração de que na maioria das vezes são usuários de substâncias psicoativas, estão em risco e têm sua força de trabalho explorada. Finalizaremos o artigo com mais um exemplo de criminalização de jovem pobre por tráfico. A situação foi vivenciada por um adolescente que se descolou de sua cidade e foi até a região da fronteira com o Paraguai buscar maconha, tendo sido apreendido em uma rodoviária da região com $826 \mathrm{~g}$ de Cannabis sativa. Antecipamos que a sentença em questão apresenta um conjunto de elementos que comprovam o quanto o adolescente é culpabilizado por uma série de questões que independem dele e, em consequência disso, perde o direito à liberdade. Observemos,

[...] Insta salientar que o representado afirmou que não trabalha e não quis informar de que forma adquire dinheiro para manter-se e ainda afirmou que a droga apreendida seria para consumo próprio, no prazo de cinco meses, a qual the custou a quantia de $\mathrm{R} \$ 80,00$. Imperioso salientar que, em que pese o representado ter alegado que a droga apreendida era para uso próprio, o mesmo tentou se eximir das consequências de seus atos, haja vista que um cigarro de maconha pesa em média de $0,5 \mathrm{~g}$ a $1,0 \mathrm{~g}$ da planta. Assim, considerando que o tablete, da substância Cannabis sativa, vulgarmente conhecida por maconha, que contém tetraidrocanabinol, apreendido em poder do adolescente pesava aproximadamente 0,826 (oitocentos e vinte e seis gramas), poder-se-ia fazer 826 a 1.652 cigarros, sendo esta tese incapaz de afastar sua culpabilidade, revelando desta forma que o representado está envolvido com o mundo ilícito, motivo pelo qual necessita de intervenção imediata. Assim sendo, [...] é de se julgar 
procedente a representação com aplicação de medida socioeducativa, posto que o representado agiu com dolo, isto é, com livre vontade e consciência de praticar ato infracional tipificado no artigo 33, caput, da Lei n. 11.343/2006, trazendo consigo, dolosamente, substância entorpecente capaz de causar dependência física e psíquica, para comercialização a terceiros, sem autorização ou em desacordo com determinação legal ou regulamentar. [...] (Sentença 2).

O primeiro ponto a ser destacado se refere a quantidade de maconha transportada, ou seja, 0,820 gramas, quantidade que o adolescente alegou ser para uso próprio. Todavia, o Poder Judiciário não entendeu desta maneira, fazendo inclusive cálculos de quantos cigarros de maconha poderiam ser feitos com aquela quantidade, enquadrando-o no artigo 33. do SISNAD, afirmando que a compra da droga seria para a comercialização a terceiros. Neste contexto o representante do Ministério Público sugere medida de internação, porém, a defensora sugeriu medida socioeducativa de Liberdade Assistida e outras medidas protetivas, especialmente "inclusão de programa comunitário ou oficial de auxílio à família, à criança e ao adolescente e inclusão em programa oficial ou comunitário de auxílio, orientação e tratamento a alcoólatras e toxicômanos" (Sentença 2), o que foi desconsiderado pelo Juiz.

Ao mencionar o "Relatório Informativo", o magistrado destaca que,

[...] demonstra que o representado faz uso abusivo de maconha e não está interessado em fazer tratamento contra drogadição; não está matriculado em rede de ensino; não está inserido em programas sociais, tampouco profissionalizante. Consta ainda que, quando o adolescente tinha três anos de idade, sua genitora abandonou o lar, ficando a educação daquele a cargo do genitor. Durante o período em que permanece no Cense, o adolescente mantém comportamento estável, não sendo necessária a aplicação de medida disciplinar. Por fim, a equipe técnica não se manifestou acerca da aplicação de medida socioeducativa [...] (Sentença 2).

Não foi levado em conta o fato de a equipe técnica (aqui se inclui um profissional de Serviço Social) do Centro de Socioeducação ter mencionado no relatório que o adolescente "faz uso abusivo de maconha". O relatório produzido pela equipe técnica também informou que o adolescente teve os direitos fundamentais negados, mas esta negação depõe contra ele. Além disso, há o relato de que ele foi abandonado pela mãe quando tinha três anos de idade e estava sob os cuidados do pai e o entendimento do juiz foi de que a família é "desestruturada", 
usando, mais uma vez, a realidade do adolescente contra ele. Ressaltamos ainda que o Juiz apontou que a equipe técnica não sugeriu medida, portanto, se omitiu quando poderia problematizar todas as contradições vivenciadas pelo jovem e, mais que isso, sugerir intervenções diferentes da privação de liberdade. Este ponto é também crucial para refletir sobre questão do adolescente autor de ato infracional.

Ao final, o magistrado utiliza como argumento os antecedentes infracionais ocorridos em outra Comarca para justificar a aplicação de medida socioeducativa em meio fechado, reforçando a questão do envolvimento com o tráfico de drogas e o comprometimento com o "mundo ilícito", vejamos,

[...] Com efeito, verifica-se que o representado está comprometido com o mundo ilícito, eis que transportava, dolosamente, substância entorpecente capaz de causar dependência física e psíquica, para comercialização a terceiros, sem autorização ou em desacordo com determinação legal ou regulamentar, constatando-se desta forma que está efetivamente envolvido com o mundo ilícito, bem como não possui internalizadas as normas socialmente aceitas, demonstrando seu descaso com a justiça. Portanto, constata-se a necessidade da aplicação da medida socioeducativa em meio fechado, eis que estão presentes os requisitos previstos no artigo 122, inciso I, do ECA, para aplicação da medida socioeducativa prevista no artigo 112, inciso VI (internação), do mesmo diploma legal, corroborado pelo princípio da proteção integral, que objetiva a intervenção psicopedagógica, a orientação ao convívio social, a internalização de valores e conceitos de respeito as leis, à vida, ao patrimônio e à sociedade. [...] (Sentença 2)

Vemos enfim que a sentença acima sintetiza diversos aspectos que tratamos no artigo, pois com base no discurso proibicionista priva um adolescente pobre de sua liberdade. Será que o transporte de 0,820 gramas de maconha poderia ser considerado como elemento que justifica a privação de liberdade de um adolescente? Vemos, portanto, que para este adolescente a "Lei Anti-Drogas" (Lei n. 11.343/2006) foi instrumento utilizado para justificar a sua apreensão, materializando a dicotomia usuário $\mathrm{X}$ traficante. É visível que o adolescente em questão faz parte de grupos vulneráveis socialmente, portanto, podemos verificar que a motivação ao encarceramento também se traduz na questão de classe. Argumentos semelhantes se repetem em várias sentenças que analisamos comprovando a tese de Löic Wacquant e outros autores que problematizam a questão da criminalização da pobreza a partir da negação de direitos e, pior que isso, são 
argumentos que comprovam o quanto a "guerra as drogas" é uma guerra que penaliza e encarcera a juventude pobre.

\section{Alguns elementos para continuidade da reflexão}

Crianças vitimadas por ausências de direitos, logo, adolescentes vitimados pelas mesmas ausências, como nos confirmam as sentenças anteriores e outras com as quais nos deparamos no desenvolvimento da pesquisa. Esta situação se repete incansavelmente, mostrando que alguns adolescentes que antes foram crianças em situação de vulnerabilidade social, agora ganham visibilidade, pois, de uma forma ou outra, são considerados, pelos discursos ideologizados, como mais algozes que vítimas. Lembremos que essa forma de olhar mostra-se a partir de fragmentações maniqueístas que distinguem, sem mediação, bem e mal, algoz e vítima.

A situação se agrava ainda mais quando se trata do narcotráfico e da construção ideológica do traficante como inimigo social. É evidente que há uma distinção de classe na atribuição do status de traficante perigoso para adolescentes em situação de vulnerabilidade social, sem a consideração de que estes são trabalhadores de um dos negócios mais lucrativos mundialmente. Um negócio que se sustenta na proibição, fazendo com que as mercadorias comercializadas tenham valor agregado. A reflexão acerca das drogas e do narcotráfico deve sair do âmbito da Segurança Pública e adentrar outros universos, pois, como mostramos no debate citado anteriormente, a "guerra às drogas" só tem razão de existir para o controle político e social de grupos socialmente "marginalizados".

Este debate se faz essencial para que profissionais do Serviço Social estejam (re)construindo olhares e estratégias de intervenção, garantindo desta forma a efetivação dos princípios éticos da profissão. A atuação nas diferentes áreas, principalmente, no campo sociojurídico, exige que o profissional tenha um olhar crítico a respeito da realidade dos adolescentes envolvidos com a criminalidade, especialmente, daqueles que têm sua força de trabalho explorada pelo narcotráfico. É essencial que as equipes técnicas, que via de regra envolvem Assistentes Sociais e Psicólogos, estejam atentas para o significado da privação de liberdade e tenham consciência do papel que os "Relatórios" e "Pareceres" desempenham em toda essa lógica penalizadora. E, principalmente, considerem que os meninos e meninas trabalhadores do tráfico de drogas estão inseridos em processos imensamente con- 
traditórios, pois por um lado são vitimados pelas demandas da questão social e, certamente, sofrem cotidianamente a pressão do envolvimento em atividades ilegais, sendo ameaçados, explorados e violentados, por outro, esses jovens recebem o status de traficantes e são demonizados por discursos moralistas. Enfim, os adolescentes trabalhadores do tráfico de drogas proibidas são apenas a ponta do iceberg e precisam de proteção, não de prisão.

Recebido em 3/6/2013 - Aprovado em 12/6/2013

\section{Referências bibliográficas}

BATISTA, Nilo; BATISTA, Vera Malaguti. Todo crime é político. Entrevistadores: Hugo R.C. Souza, Luciana Gondim, Maurício Caleiro, Paula Grassiani, Rodolfo Torres e Sylvia Moretzsohn. Caros Amigos, São Paulo, ano 7, n. 77, p. 28-33, ago. 2003.

BOITEUX, Luciana. A nova lei antidrogas e o aumento da pena do delito de tráfico de entorpecentes. Boletim IBCCrim, São Paulo, ano 14, n. 167, p. 8-9, out. 2006.

BRASIL. Decreto n. 3.597, de 12 de setembro de 2000. Promulga Convenção 182 e a Recomendação 190 da Organização Internacional do Trabalho (OIT) sobre a Proibição das Piores Formas de Trabalho Infantil e a Ação Imediata para sua Eliminação.

. Lei n. 11.343, de 23 de agosto de 2006. Institui o Sistema Nacional de Políticas Públicas sobre Drogas — SISNAD.

. Estatuto da Criança e do Adolescente: Lei n. 8069 de 13 de julho de 1990.

. Lei n. 10.409, de 11 de janeiro de 2002. Dispõe sobre a prevenção, o tratamento, a fiscalização, o controle e a repressão à produção, ao uso e ao tráfico ilícitos de produtos, substâncias ou drogas ilícitas que causem dependência física ou psíquica, assim elencados pelo Ministério da Saúde, e dá outras providências.

CARNEIRO, Henrique S. As necessidades humanas e o proibicionismo das drogas no século XX. Outubro, São Paulo, v. 6, p. 115-128, 2002.

D'ELIA FILHO, Orlando Zaccone. Acionistas do nada: quem são os traficantes de drogas. Rio de Janeiro: Reavan, 2008.

DELMANTO, Júlio. Imperialismo e proibicionismo: raízes e interesses da proibição das drogas e da suposta guerra ao tráfico. 2010b. Disponível em: $<$ http://www.neip.info/index. php/content/view/1459.html>. Acesso em: 15 mar. 2012. 
ESCOHOTADO, Antônio. História elementar das drogas. Lisboa: Antígona, 2004.

FERNANDEZ, Osvaldo. Drogas e (des)controle social. In: PASSETTI, Edson; SILVA, Roberto B. Dias. (Orgs.). Conversações abolicionistas: uma crítica do sistema penal e da sociedade punitiva. São Paulo: IBCCrim, 1997.

KARAM, Maria Lucia. Não são as drogas que causam violência e criminalidade. Entrevistador: Fórum da Liberdade. 7 fev. 2012. Disponível em: <http://forumdaliberdade.com. br/fl25/blog/2012/nao-sao-as-drogas-que-causam-violencia-e-criminalidade-afirma-maria-lucia-karam/>. Acesso em: 20 fev. 2012.

KOUTOUZIS, Michel (Coord.). Atlas mondial des drogues. Observatoire Géopolitique des Drogues. 2. ed. Paris: Presses Universitaires de France, 1997.

LABROUSSE, Alain. Geopolitica das drogas. Tradução de Mônica Seincman. São Paulo: Destino, 2010.

LIMA, Rita de Cássia Cavalcante. Uma história das drogas e do seu proibicionismo transnacional: relações Brasil-Estados Unidos e os organismos internacionais. 2009. 365 f. Tese (Doutorado em Serviço Social), Universidade Federal do Rio de Janeiro, Rio de Janeiro, 2009.

MARONNA, Cristiano Ávila. Nova lei de drogas: retrocesso travestido de avanço. Boletim do IBCCRIM, São Paulo, v. 14, n. 167, p. 4, out. 2006.

MARX, Karl. O capital: crítica da economia política. V. 1 e 2. São Paulo: Nova Cultural, 1988. (Economistas)

PASSETTI, Edson. Das fumeries ao narcotráfico. São Paulo: Educ, 1991.

ROCHA, Andréa Pires. Trajetórias de adolescentes apreendidos como "mulas" do transporte de drogas na região da fronteira (Paraná) Brasil-Paraguai: exploração de força de trabalho e criminalização da pobreza. 2012. 396 f. Tese (Doutorado em Serviço Social) Faculdade de Ciências Humanas e Sociais, Universidade Estadual Paulista "Júlio de Mesquita Filho", Franca/SP, 2012.

RODRIGUES, Thiago M. S. Narcotráfico: uma guerra na guerra. São Paulo: Desatino, 2003. WACQUANT, Loïc. Castigar a los pobres: el gobierno neoliberal de la inseguridad social. Tradução: Margarita Polo. Barcelona: Gedisa, 2010.

. As prisões da miséria. Tradução de André Telles. Rio de Janeiro: Jorge Zahar, 2001. 